\title{
Petrologia e sucessão estratigráfica das rochas monzoníticas da associação shoshonítica de Lavras do Sul (RS)
}

\author{
Joaquim Daniel de Liz', Evandro Fernandes de Lima ${ }^{1}$, Lauro Valentim Stoll Nardi', \\ Carlos Augusto Sommer ${ }^{1}$, Dejanira Luderitz Saldanha ${ }^{1} \&$ Ronaldo Pierosan $^{1}$
}

\begin{abstract}
Resumo São discutidos os apectos de campo, a geoquímica de elementos maiores, traços e isótopos das rochas monzoníticas da região de Lavras do Sul, extremo sul do Brasil. Estas ocorrem como intrusões epizonais (Monzonito Tapera e Monzodiorito Arroio do Jacques) e como corpos subvulcânicos (Monzonitos Hipabissais), cuja distribuição e forma são relacionadas a sistemas de subsidência de caldeiras. Os Monzonitos Hipabissais e os diques relacionados são intrusões ressurgentes com orientação NW-SE. As fases minerais máficas destas rochas são constituídas por magnésio hornblenda, augita-diopsídio e biotita. Dados geoquímicos indicam que os monzonitos são cogenéticos, pertencem a Associação Shoshonítica de Lavras do Sul (ASLS) e foram gerados por cristalização fracionada a partir de magmas menos diferenciados. A idade obtida de $587 \pm 4$ Ma (SHRIMP-U-Pb em zircão) obtida nos Monzonitos Hipabissais representa as manifestações shoshoníticas tardias da área e definem um intervalo de formação da ASLS de pelo menos $16 \mathrm{Ma}$.
\end{abstract}

Palavras-chave: shoshonitos, geocronologia, monzonitos.

\begin{abstract}
Geology and petrology of the monzonitic rocks of the Lavras do Sul shoshonitic association (LSSA). The monzonitic plutonic and hypabissal rocks from the Lavras do Sul region, southernmost Brazil, are discussed in this paper, mainly with basis on field relationship, and major, trace-element and isotope geochemistry of rocks. The monzonitic rocks of Lavras do Sul Shoshonitic Association (LSSA) occur as epizonal intrusions (Tapera Monzonite and Arroio do Jacques Monzodiorite) and hypabissal bodies, whose distribution and form are related to caldera subsidence. Hypabissal Monzonites and coeval dikes are resurgent intrusions with NW-SE orientation. Their mafic phases are magnesium hornblende, augite-diopside and biotite. Geochemical data suggest that the monzonitic rocks are cogenetic and belong to the LSSA and, were derived from less differentiated magmas through fractional crystallization. The obtained age ( $587 \pm 4 \mathrm{Ma}$ by $\mathrm{U}-\mathrm{Pb}$ in zircon, SHRIMP) for the Hipabissal Monzonites, which is related to the late stages of shoshonitic magmatism in this area, define a range of at least $16 \mathrm{Ma}$ for this magmatism.
\end{abstract}

Keywords: shoshonites, geochronology, monzonites.

INTRODUÇÃOO O termo "monzonito" foi criado por Lapparent (1864) para designar as rochas do Complexo Monzoni no Tyrol, originalmente denominadas de "monzosienitos" por Von Buch (1824). Segundo Lapparent esta denominação teria um caráter geológico genérico descritivo sem a pretensão de ser aplicada como uma classificação petrográfica. Brögger (1895) foi o primeiro a utilizar o termo monzonito para classificar rochas ígneas plutônicas, feldspáticas, com proporções semelhantes entre ortoclásio e plagioclásio, independentemente da concentração de quartzo modal.

A definição de monzonito permanece controversa e mantida em alguns países (p.ex. Estados Unidos) a definição de Brögger (1895) e em outros como equivalentes de sienodiorito e ferrodiorito (p.ex. Complexo Marsco na Escócia, conforme Wager \& Vincent (1962). Constata-se também que o termo monzonito é utilizado em alguns casos para associações minerais em desequilíbrio, correspondendo a líquidos traquíticos com razões $\mathrm{Ab} / \mathrm{Or}$ normativo em torno de 1, que foram rapidamente cristalizados (Stabel et al. 2001). Estes, em geral, ocorrem associados aos sienitos e sua gênese pode ser explicada com base nos trabalhos experimentais de Nekvasil (1992).

O termo monzonito, bem como outras denominações utilizadas no presente trabalho, segue as especificações e recomendações da IUGS descritas em Le Maitre (2002).

A Associação Shoshonítica de Lavras do Sul (Nardi \& Lima 1985), situada na região de Lavras do Sul (extremo sul do Brasil), tem idade neoproterozóica e apresenta características de um magmatismo póscolisional (Lima \& Nardi 1998), relacionando-se aos estágios finais da Orogenia Brasiliana.

As rochas monzoníticas são constituintes importantes da ASLS e ocorrem, preferencialmente, em uma estrutura semicircular na porção norte da área e como intrusões ressurgentes rasas na fácies efusiva, sendo estas rochas vinculadas a uma estruturação de colapso de caldeira. Esta hipótese, inicialmente suge- 
rida por Lima (1995), foi apresentada e discutida por Gastal et al. (2006) a partir de dados geofísicos.

Conforme Liz et al. (2004) as rochas monzoníticas apresentam características estruturais e texturais que sugerem uma gênese a partir de um sistema multiintrusivo estabelecido provavelmente em um ambiente do tipo caldeira.

O presente artigo visa à investigação dos termos monzoníticos plutônicos e hipabissais da porção norte da área de Lavras do Sul, com base em relações de campo, litogeoquímica, geoquímica isotópica e de química mineral, com o intuito de contribuir com a ordenação dos eventos geológicos da área.

PROCEDIMENTOS ANALÍTICOS $\mathrm{Na}$ construção do mapa geológico foram utilizados dados de campo aliados a interpretação de imagens do sensor Aster com resolução espacial de 15 e $30 \mathrm{~m}$.

Os estudos litoquímicos fundamentaram-se nas análises químicas de vinte amostras representativas dos diferentes litotipos. Os elementos maiores e traços foram analisados no Activation Laboratories Ltd., Ontario, Canada, utilizando a técnica de ICP (Inductively Coupled Plasma) para os elementos maiores e ICP-MS (Inductively Coupled Plasma Microspectrometry) para os elementos traço e terras raras.

Nos estudos de química mineral foram investigados os minerais silicatados dos monzonitos e quartzo Monzonitos Hipabissais. Estes minerais foram analisados por microssonda eletrônica no Laboratório de Microssonda Eletrônica do CPGq-IG-UFRGS, utilizando o equipamento marca CAMECA, modelo SX-50 sob as seguintes condições experimentais: para os minerais silicatados utilizou-se um potencial de aceleração $15 \mathrm{kV}$, corrente de $10 \mathrm{nA}$ e diâmetro do feixe de elétrons de $5 \mu \mathrm{m}$, com tempo de integração de contagens 8 ou 10 s e correção ZAF.

Para o estudo geocronológico foi selecionada uma amostra representativa do monzonito hipabissal, da qual foram obtidos vinte grãos de zircão, a partir de técnicas de separação magnética seguida de líquidos densos. As análises foram realizadas na Universidade de Curtin (Oeste da Austrália), com base no método de datação U-Pb SHRIMP segundo os procedimentos de Compston et al. (1984) e Smith et al. (1998).

CONTEXTO GEOLÓGICO A região de Lavras do Sul localiza-se na porção oeste do Escudo Sul-RioGrandense e é caracterizada, na área estudada, por um embasamento constituído de metagranitóides (Complexo Cambai) e xistos (Metamorfitos Arroio da Porteira) relacionados ao Ciclo Brasiliano, que são parcialmente cobertos por rochas sedimentares da Formação Maricá. Este conjunto foi sobreposto e intrudido por rochas básicas a ácidas da ASLS (Nardi \& Lima 1985). Granitos e vulcanitos ácidos e básicos, de afinidade alcalina sódica saturada em sílica (Formação Acampamento Velho), e rochas sedimentares da Formação Santa Bárbara sucedem esta associação (Fig. 1).

A ASLS tem idade neoproterozóica (Nardi \& Lima 1985) e apresenta características de um magma- tismo pós-colisional relacionando-se aos estágios finais da Orogenia Brasiliana. A ASLS possui na base traquibasaltos potássicos, sucedidos por quatro ciclos efusivos shoshoníticos, além de depósitos piroclásticos correlatos (Lima 1995). Os corpos intrusivos contemporâneos aos vulcanitos da base foram datados por Gastal \& Lafon 2001 e são representados pelo Monzodiorito Arroio do Jacques (599 $\pm 7 \mathrm{Ma})$ e pelo Monzonito Tapera $(601 \pm 5 \mathrm{Ma})$. O primeiro ocorre como um corpo alongado com direção NW-S e extensão de $2,5 \mathrm{~km}$ por $1 \mathrm{~km}$ de largura, sendo constituído por monzodioritos, quartzo monzodioritos e, subordinadamente, ortopiroxênio dioritos, atingindo, localmente, composições monzoníticas. O Monzonito Tapera apresenta zonação normal e formato de meia-lua e é caracterizado por dioritos e leucodioritos que evoluem, em direção ao sul, para monzodioritos e monzonitos. São temporalmente anteriores aos granitos do núcleo (granodiorito a monzogranito) e ao pertita granito que apresentam idades de $594 \pm 5 \mathrm{Ma}$ (Remus et al. 2000). Gastal et al. (2006), com base em novos dados geocronológicos e reinterpretados de Remus et al. (2000), sugerem que o Monzonito Tapera, o Monzodiorito Arroio do Jacques e os granitos do núcleo são cronocorrelatos $(\approx 600 \mathrm{Ma})$, enquanto que o pertita granito cristalizou em torno de $586 \mathrm{Ma}$. Estas unidades intrusivas foram reunidas por estes autores no Complexo Intrusivo de Lavras do Sul (CILS).

No presente trabalho identificou-se uma nova unidade denominada informalmente de Monzonitos Hipabissais, que compreende monzonitos e quartzo monzonitos subvulcânicos concentrados na borda nordeste do Complexo Granítico de Lavras, tendo uma destas intrusões um padrão geométrico semicircular. Esta morfologia é comum em terrenos vulcânicos associados ao colapso de caldeiras, sendo esta hipótese coerente com sugestões anteriores (Lima 1995, Gastal et al. 2006 e Gastal \& Lafon 2006). Estes litotipos representam intrusões ressurgentes tipo finger com direção, predominante, NW-SE que secionam o Monzonito Tapera, o Monzodiorito Arroio do Jacques, os shoshonitos e a borda nordeste do Complexo Granítico de Lavras, conforme a definição de Nardi (1984).

Temporalmente vinculados aos Monzonitos Hipabissais ocorrem os diques riolíticos de espessuras decamétricas e as últimas manifestações efusivas intermediárias. Manifestações latíticas estão representadas por diques decamétricos com direção NW-SE na porção nordeste de Lavras do Sul.

PETROGRAFIA Os dados de campo permitem individualizar as seguintes unidades: Monzonito Tapera, Monzodiorito Arroio do Jacques, Monzonitos Hipabissais e diques intermediários. Dados de química mineral (Lima 1995, Liz et al. 2004 e de Gastal et al. 2004) acompanham a síntese petrográfica da unidade hipabissal e dos diques relacionados. Os dados petrográficos das rochas monzoníticas foram representados no sistema de classificação QAPF (Fig. 2).

O Monzonito Tapera pode ser dividido com base no QAP em três composições: diorítica, monzodioríti- 


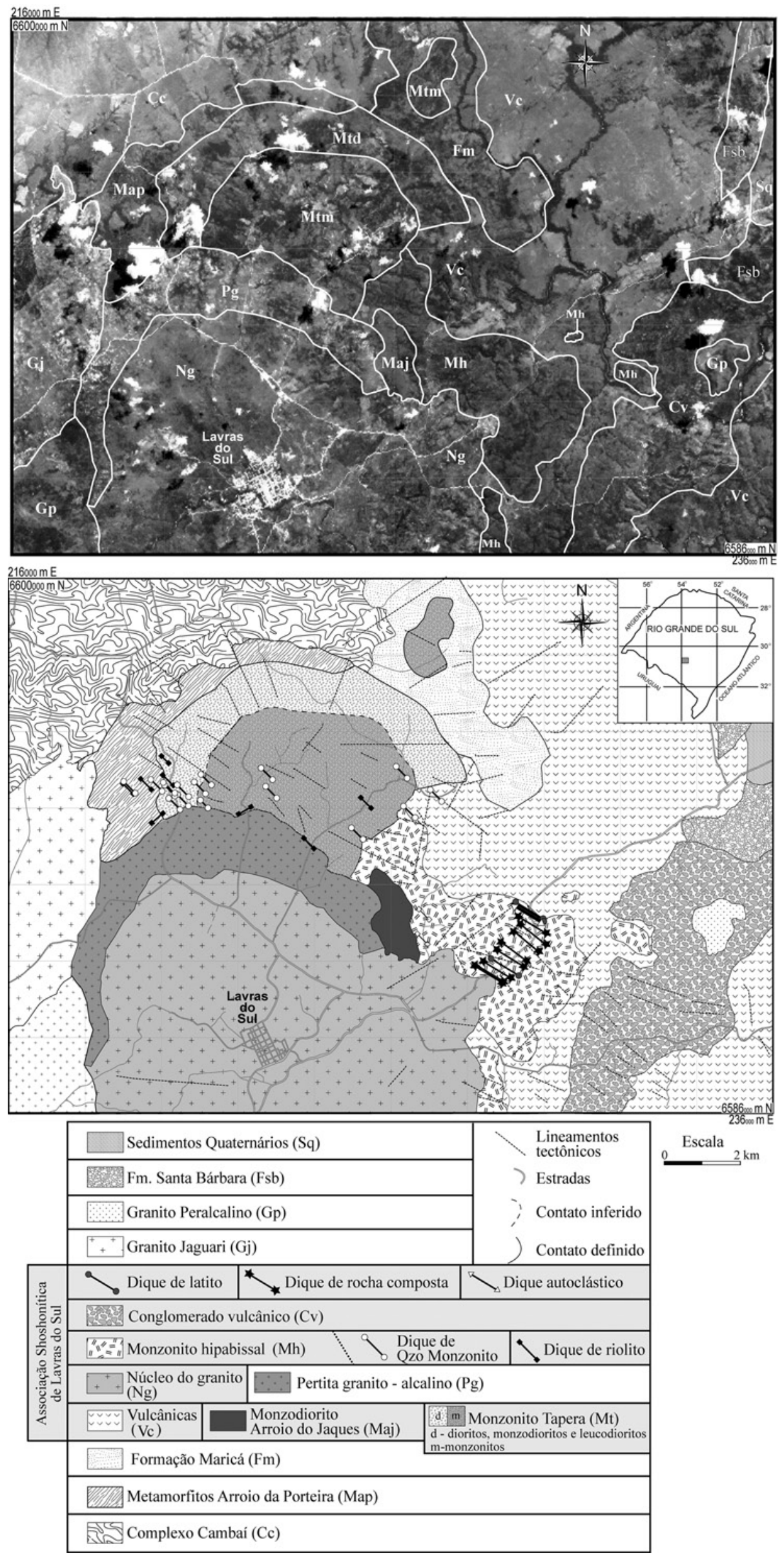

Figura 1 - Mapa geológico da porção norte de Lavras do Sul e representação em imagem Aster. 


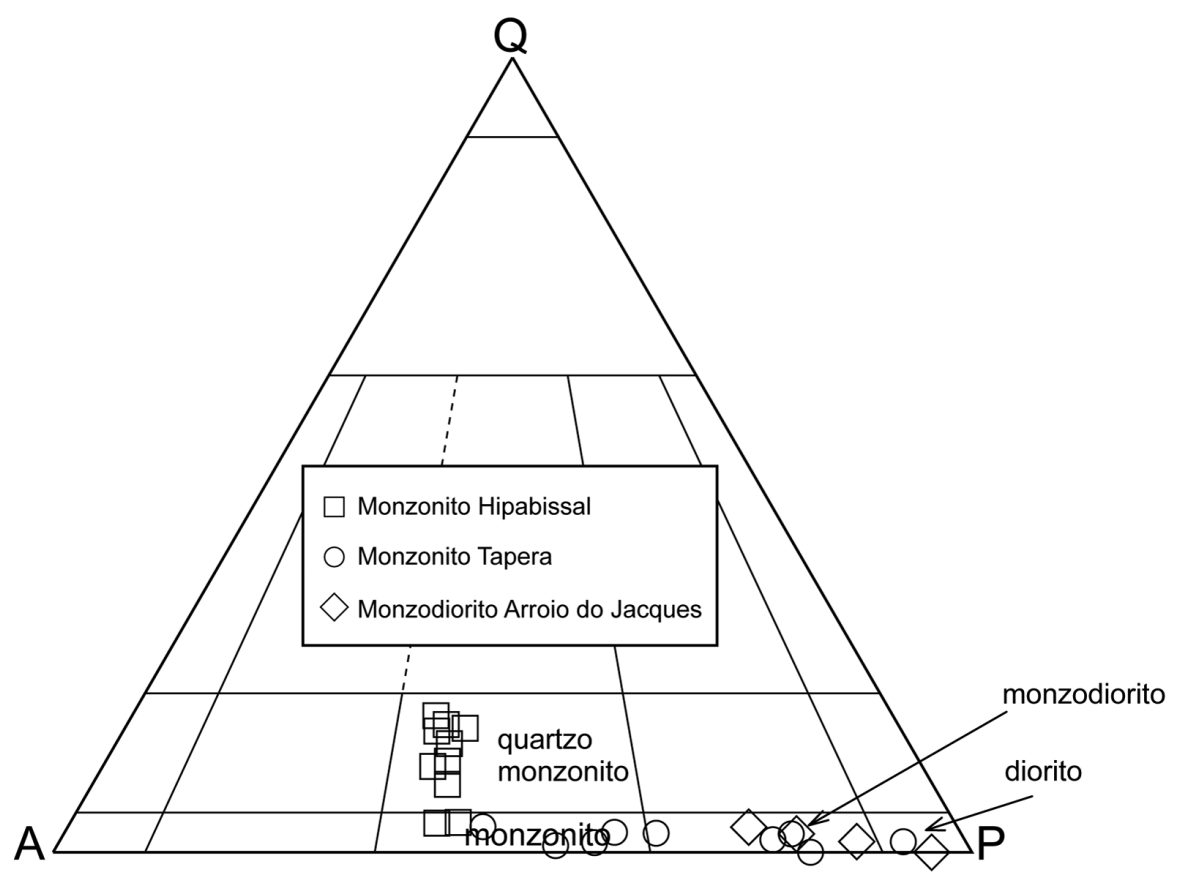

Figura 2 - Diagrama QAP ilustrando as variações composicionais das rochas monzoniticas da ASLS.

ca e monzonítica. Os dioritos ocupam a porção mais externa do corpo e são constituídos por plagioclásio, acompanhados por augita, hornblenda, biotita e opacos com textura equigranular média a fina (Fig. 3a). Esta porção evolui internamente para leucodiorito (Fig. 3b), que forma pequenas faixas decamétricas com textura equigranular grossa a média, sendo dominantemente um adcumulado, com zonas ortocumuláticas próximas as porções porfiríticas. Nas zonas ortocumuláticas a rocha é formada por cumulus de plagioclásio (70\%-80\%) e clinopiroxênio parcialmente transformado para hornblenda e biotita. O intercumulus é composto por feldspato alcalino, quartzo, com acessórios caracterizados por apatita, opacos, alanita e titanita. Nas porções $a d-$ cumuladas os cumulus são formados por grãos de plagioclásio (50\%-60\%), oticamente definido como oligoclásio e andesina, feldspato alcalino pertítico, augita, hornblenda e biotita, com o intercumulus representado por feldspato alcalino, quartzo e zircão, apatita, opacos, alanita e titanita como minerais acessórios. $\mathrm{O}$ aumento da quantidade de feldspato alcalino com a evolução magmática gera composição monzodiorítica (Fig. 3c), que mantém as características texturais. A evolução do corpo culmina com a ocorrência de monzonitos (Fig. 3d), mantendo a textura equigranular grossa a média e a característica adcumulada, ocorrendo ainda porções porfiríticas localizadas. Nos termos equigranulares a associação mineral cumulus compreende plagioclásio e feldspato alcalino pertítico acompanhado de augita, hornblenda e biotita, com o intercumulus representado por feldspato alcalino, quartzo e os acessórios: zircão, apatita, opacos, alanita e titanita. Nas porções porfiríticas ocorrem megacristais de feldspato alcalino envolvidos por uma matriz grossa a média $(8 \mathrm{~mm}$ a $3 \mathrm{~mm})$ composta por fenocristais de plagioclásio, feldspato alcalino, clinopiroxênio, hornblenda e biotita, sendo os acessórios: zircão, apatita, opacos, alanita e titanita.

O Monzodiorito Arroio do Jacques é caracterizado por rochas com textura, dominantemente, equigranular média a fina (Fig. 3e). Esta unidade é constituída, segundo Gastal et al. (2004), por monzodioritos e quartzo monzodioritos e, subordinadamente, por ortopiroxênio dioritos que evoluem até monzonitos. Os minerais essenciais são plagioclásio (oligoclásio e andesina) e feldspato alcalino pertítico, este último com conteúdos subordinados. A associação mineral máfica compreende hiperstênio, augita, hornblenda e biotita, e como acessórios ocorrem zircão, ilmenita e apatita.

Os Monzonitos Hipabissais são porfiríticos e, subordinadamente, equigranulares (Fig. 3f). Possuem um índice feldspático em torno de 40 e predomina a composição quartzo monzonítica. As rochas com textura porfirítica são compostas por megacristais de feldspato alcalino pertítico, com dimensões de 1 a $5 \mathrm{~cm}$ e fenocristais subédricos a euédricos de plagioclásio e hornblenda, com dimensões da ordem de $0,7 \mathrm{~cm}$, que são envolvidos por uma matriz equigranular média a fina $(2 \mathrm{~mm} \mathrm{a}<1 \mathrm{~mm})$ com K-feldspato, plagioclásio, quartzo, hornblenda, augita, biotita e minerais acessórios. O feldspato alcalino, tanto os megacristais como os constituintes da matriz de acordo com Lima (1995), possui composição variando entre sanidina a albita potássica. Em geral, ocorre com hábito tabular arredondado, observando-se em alguns casos textura rapakivi, com anel de plagioclásio com $\mathrm{An}_{15}$. A presença de inclusões de plagioclásio e anfibólio no feldspato alcalino sugere uma cristalização mais tardia desta fase. O plagioclásio varia de oligoclásio a andesina, sendo comuns teores de 

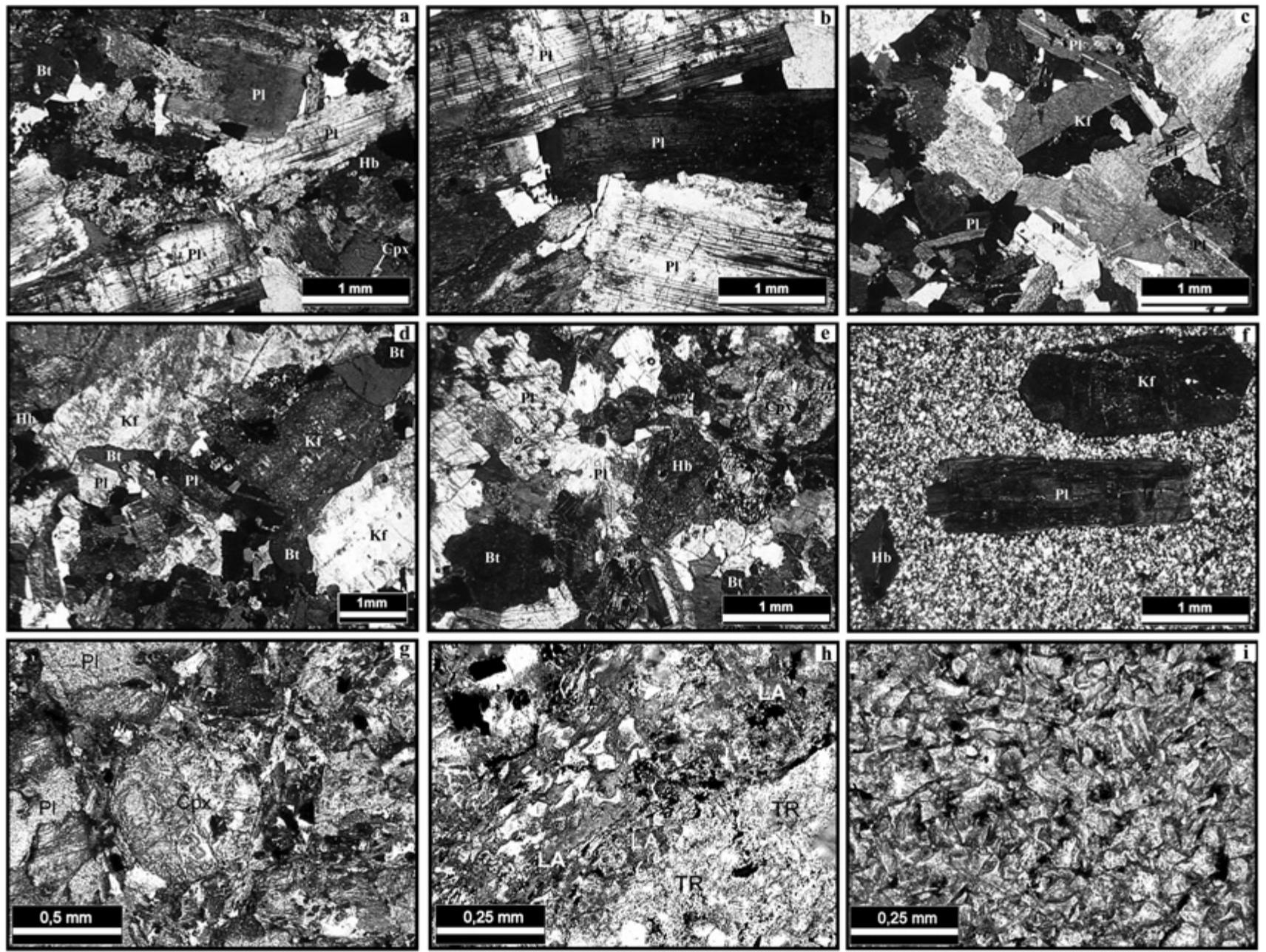

Figura 3 - Fotomicrografias em luz polarizada das seguintes unidades: a) fácies diorítica do Monzonito Tapera com grãos de plagioclásio (Pl), clinopiroxênio (Cpx), hornblenda (Hb) e biotita (Bt) formando textura equigranular média; b) fácies leucodiorítica do Monzonito Tapera com zona ortocumulática com empilhamento de grãos de plagioclásio (pl); c) fácies monzodiorítica do Monzonito Tapera com textura equigranular média formada dominantemente por plagioclásio (Pl) com conteúdos subordinados de feldspato alcalino (Kf); d) fácies monzonítica do Monzonito Tapera com grãos de feldspato alcalino (Kf) com dimensões destacadas em relação a plagioclásio (Pl), biotita (Bt) e hornblenda (Hb); e) Monzodiorito Arroio do Jacques com textura equigranular com grãos de plagioclásio (Pl), clinopiroxênio (Cpx), hornblenda (Hb) e biotita (Bt); $f$ ) Monzonito Hipabissal com textura porfirítica definida por fenocristais de feldspato alcalino (Kf), plagioclásio (Pl) e hornblenda $(\mathrm{Hb})$ envolvidos por uma matriz fanerítica fina composta por plagioclásio, feldspato alcalino e quartzo; g) fenocristais de augita (Cpx) e plagioclásio (Pl) de dique latítico; h) porção vítrea evidenciando o contato entre as composições latíticas (LA) e traquítica (TR) da rocha composta e i) fragmentos vitreos com formas tabular, curviplanar e cúspide do dique autoclástico.

Or de 5\% a 7\% na andesina e de até 3\% no oligoclásio. Dados de química mineral discutidos por Lima (1995) permitem classificar os minerais máficos como augita $\left(\mathrm{Wo}_{45-46} \mathrm{En}_{32-33} \mathrm{Fs}_{22-23}\right)$, magnésio-hornblenda e biotita. Segundo este autor a substituição edenítica é comum no anfibólio e está relacionada com a evolução magmática do sistema. Os conteúdos de $\mathrm{Al}_{\text {total }}$ versus $\mathrm{Mg}$ da biotita coincidem com os de granitóides subalcalinos metaluminosos (Nachit et al. 1985). As razões de $\mathrm{FeO} /$ $(\mathrm{FeO}+\mathrm{MgO})$ do anfibólio e da biotita variam de 0,53 a 0,60 e de 0,59 a 0,70 , semelhantes aos valores obtidos na biotita dos granitóides do núcleo do Complexo Gra- nítico de Lavras do Sul. A associação mineral acessória é constituída por prismas de apatita, zircão com hábito arredondado, titanita subédrica e grãos de titanomagnetita com lamelas de exsolução de ilmenita.

Os diques intermediários definidos por Liz et al. (2004) compreendem três tipos principais: latíticos $(3 \mathrm{~g})$, rocha composta ( $3 \mathrm{~h})$ e rocha autoclástica (3i). Os diques latíticos ocorrem com direção NW-SE e possuem espessuras que variam de 3 a $60 \mathrm{~m}$ em afloramento. Estas intrusões são sincrônicas a posteriores em relação aos corpos monzoníticos. Os diques latíticos apresentam contatos lobados com os monzonitos, suge- 
rindo um posicionamento antes do final da cristalização da rocha hospedeira, enquanto que os diques posteriores possuem contatos retos com os monzonitos e lobados com a rocha composta. Lima (1995) coloca como uma característica marcante destas rochas é a presença de fenocristais de plagioclásio $\left(\mathrm{An}_{40-42}\right)$ e augita $\left(\mathrm{Wo}_{43-}\right.$ ${ }_{44} \mathrm{En}_{39} \mathrm{Fs}_{18}$ ), envolvidos por uma matriz hemicristalina rica em micrólitos e cristálitos de feldspatos. Os minerais acessórios são magnetita e apatita, que, em alguns casos, ocorrem como microfenocristais subédricos a euédricos. Os diques de rocha composta representam composições heterogêneas latíticas e traquíticas, de acordo com o diagrama TAS (Liz et al. 2004). Este litotipo ocorre como diques, com espessuras da ordem de 5 a $60 \mathrm{~m}$, que cortam os monzonitos segundo direção NW-SE. Possui uma textura afanítica, sendo as porções latíticas cinza-esverdeadas entremeadas com porções traquíticas amarelo-avermelhadas. Nas porções latíticas dominam fenocristais tabulares de plagioclásio $\left(\mathrm{An}_{40-42}\right)$, grãos subarredondados de augita $\left(\mathrm{Wo}_{42-}\right.$ ${ }_{43} \mathrm{En}_{36} \mathrm{Fs}_{21-22}$, envolvidos por uma matriz hemicristalina rica em micrólitos e cristálitos de plagioclásio orientados, definindo uma textura traquítica, enquanto nas porções traquíticas os fenocristais são representados por feldspato micropertítico envolvidos por porções vítreas além de raros micrólitos de feldspato potássico com $\mathrm{Or}_{95}$. A presença de vesículas é comum, sendo, em alguns casos, concentradas no domínio latítico. Sulfetos disseminados são comuns, em geral, associados às vesículas. O dique de rocha autoclástica, segundo Liz et al. (2004), ocupa o campo do dacito no sistema TAS e ocorre como um dique, cortando as rochas monzoníticas, com direção NW-SE e com 58 metros de espessura em afloramento. A rocha é afanítica, de coloração cinza-esverdeada, com uma superfície rugosa gerada pelo processo de autobrechação. Microscopicamente observam-se autoclastos com textura glomeroporfirítica, definida por agrupamentos de fenocristais de plagioclásio envolvidos por porções ricas em tubos de púmice brechados, fragmentos vítreos (shards) e bolhas.

\section{LITOQUÍMICA DAS UNIDADES MONZONÍTI-}

CAS A classificação das rochas foi realizada com base no sistema QAP e empregou-se o diagrama total de álcalis versus sílica (TAS) para estabelecer as composições vulcânicas equivalentes. As rochas do Monzonito Tapera ocupam no diagrama TAS (Fig. 4), o campo dos traquiandesitos e dos traquitos/traquidacitos, com $\mathrm{K}_{2} \mathrm{O}>\left(\mathrm{Na}_{2} \mathrm{O}\right.$ -2), correspondendo a composições latíticas e traquíticas , sendo o conteúdo de Qz normativo inferior a 20\% (Tab. 1). As rochas do Monzodiorito Arroio do Jacques ocupam no diagrama TAS (Fig. 4) o limite do campo dos traquiandesitos basálticos para o campo dos traquiandesitos com $\mathrm{K}_{2} \mathrm{O} \geq\left(\mathrm{Na}_{2} \mathrm{O}-2\right)$, sendo composicionalmente equivalentes a latitos. Os Monzonitos Hipabissais ocupam no diagrama TAS (Fig. 4) o campo dos traquitos e possuem conteúdos de Qz normativo inferior a 20\% (Tab. 1) .

Os teores de $\mathrm{SiO}_{2}$ das unidades variam de 55,03 $\%$ até $66,85 \%$ sendo a sílica o índice de diferenciação que melhor expressa a variação dos demais elementos (Tab.1). O padrão de distribuição dos elementos maiores versus $\mathrm{SiO}_{2}$ das rochas do Monzonito Tapera, Monzodio-

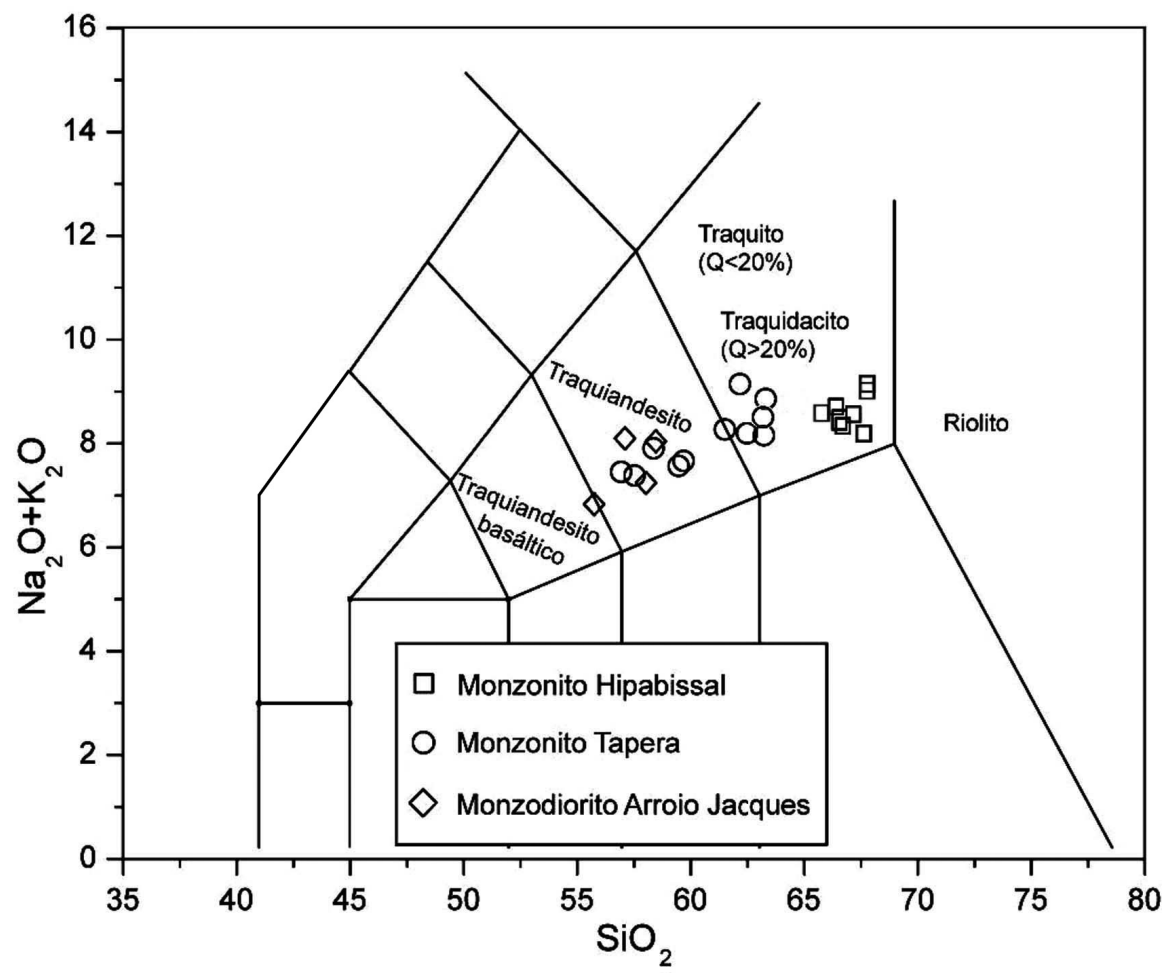

Figura 4 - Diagrama TAS - álcalis total (percentagem de peso) versus $\mathrm{SiO}_{2}$ (percentagem de peso) TAS. 
Tabela 1 - Análise química de amostras representativas das rochas monzoníticas da região de Lavras do Sul (MTMonzonito Tapera, MAJ- Monzonito Arroio do Jacques e MH - Monzonitos Hipabissais).

\begin{tabular}{|c|c|c|c|c|c|c|c|c|c|c|c|c|c|c|c|c|c|c|c|c|}
\hline & T1 & T2 & T3 & ИT4 & IT5 & TT6 & IT7 & MT8 & MT9 & MT10 & MT11 I & MAJ1 & MAJ2 & MAJ3 & MAJ4 & MH1 & $1 \mathrm{H} 2$ & MH3 & MH4 & MH8 \\
\hline & & .58 &, 05 & 8,72 & 7,77 & 1,28 & 61,64 & 61,71 & 57,02 & 55,67 & $|62,46|$ & 57,58 & 55,63 & $|57,60|$ & 55,03 & 65,80 & 6,18 & 66,85 & 65,50 & 66,28 \\
\hline $\mathrm{Al}_{2} \mathrm{O}_{3}$ & & ,93 & 6,99 & 14,24 & 3,99 & 7,41 & 16,94 & 16,41 & 19,65 & 7,15 & 15,88 & 13,16 & 14,24 & 14,81 & 12,94 & 16,19 & 6,00 & 15,76 & 14,67 & 14,95 \\
\hline $\mathrm{Fe}_{2} \mathrm{O}_{3} \mathrm{t}$ & 5,09 & 6,45 & 5,42 & 6,43 & 6,45 & 4,77 & 4,74 & 4,31 & 5,82 & 8,02 & 5,98 & 6,95 & 6,46 & 6,38 & 7,44 & 3,39 & 2,79 & 5,58 & 4,45 & 4,47 \\
\hline $\mathrm{MnO}$ & 08 & 0,09 & 10 & 0,09 & 0,09 & 0,09 & 0,09 & 0,07 & 0,10 & 0,13 & 0,11 & 0,10 & 0,08 & 0,08 & 0,10 & 0,08 &, 04 & 0,04 & 0,04 & 0,05 \\
\hline $\mathrm{IgO}$ & 34 & 6,59 & 1,79 & 4,84 & 5,02 & 1,52 & 1,51 & 1,01 & 1,79 & 2,82 & 1,20 & 6,95 & 5,88 & 5,02 & 8,03 & 1,61 &, 98 & 2,71 & 1,40 & 1,19 \\
\hline $\mathrm{CaO}$ & 41 & 5,21 & 31 & 4,99 & 5,07 & 4,13 & 3,88 & 2,51 & 6,30 & 5,16 & 3,10 & 5,70 & 5,42 & 5,05 & 6,55 & 2,90 & 2,29 & 1,80 & 2,00 & 2,24 \\
\hline $\mathrm{Ia}_{2} \mathrm{O}$ & ,70 & 3,41 & 4,62 & 3,78 & 3,66 & 4,89 &, 74 & 4,65 & 4,51 & 4,40 & 4,34 & 3,25 & 3,45 & 3,85 & 2,95 & 4,95 & 5,24 & 3,99 & 4,31 & 4,25 \\
\hline $\mathrm{K}_{2} \mathrm{O}$ & 30 & 22 & 43 & 3,73 & 3,68 & 3,12 & 3,19 & 4,74 & 2,77 & 2,82 & 4,34 & 3,91 & 4,41 & 4,04 & 3,76 & 3,68 & 3,67 & 4,60 & 4,30 & 4,20 \\
\hline $\mathrm{TiO}_{2}$ & & 1,09 & 61 & & 1,17 & 0,55 &, 52 & 0,63 & 0,83 & 1,14 & 0,92 & 1,19 & 1,36 & 1,26 & 1,35 & 0,41 & 0,31 & 0,44 & 0,40 & 0,37 \\
\hline $\mathrm{P}_{2} \mathrm{O}_{5}$ & & 0,45 & 0,33 & 0,39 & 0,39 & 0,25 & 0,25 & 0,21 & 0,37 & 0,45 & 0,34 & 0,45 & 0,48 & 0,47 & 0,56 & 0,14 & 0,14 & 0,14 & 0,10 & 0,11 \\
\hline LOI & 97 & 1,55 & 0,93 & 1,15 & 1,34 & 0,72 & 1,12 & 3,35 & 0,74 & 1,43 & 1,24 & 0,70 & 1,69 & 0,79 & 0,66 & 1,01 & 1,06 & 0,30 & 3,00 & 3,00 \\
\hline Total & 9,55 & 3,57 & 98,57 & 99,54 & 98,63 & 98,73 & 98,62 & 99,59 & 99,88 & 99,18 & 99,89 & 99,24 & 99,11 & 98,55 & 98,72 & 100,15 & 98,69 & 100,05 & 99,62 & 99,06 \\
\hline B & 141 & 166 & 740 & 1056 & 1035 & 801 & 1759 & 2080 & 1873 & 2709 & 2168 & 1210 & 1221 & 1210 & 1650 & 2149 & 2119 & 2483 & 1621 & 1695 \\
\hline $\mathrm{Sr}$ & & 776 & 245 & 713 & 694 & 1391 & 1368 & 522 & 1475 & 351 & 656 & 798 & 802 & 889 & 1080 & 1435 & 1441 & 1021 & 805 & 950 \\
\hline Y & 7,00 & 7,00 & 16,00 & 15,00 & 16,00 & $|14,00|$ & 12,00 & 18,00 & 15,00 & 15,00 & 24,00 & 15,72 & 16,00 & $|14,62|$ & 17,03 & 9,00 & 7,00 & - & - & 8,00 \\
\hline $\mathrm{Zr}$ & & 257 & 175 & & & 157 & 164 & 243 & 72 & 128 & 267 & 231 & 286 & 290 & & 114 & 129 & 20 & 236 & 235 \\
\hline $\mathrm{Rb}$ & & & & & & & & & 70 & 60 & & 124 & & & & 90 & 01 & 35 & 85 & 91 \\
\hline $\mathrm{Nb}$ & 3,50 & 21,79 & 15,89 & 22,93 & 23,54 & 14,82 & 13,42 & 15,51 & 11,19 & 11,52 & 13,68 & 23,85 & 19,08 & 27,29 & 17,18 & 5,11 & 5,21 & - & - & \\
\hline $\mathrm{La}$ & ,44 & 72,17 & 56,20 & 65,74 & 64,82 & 126,88 & 54,59 & 60,47 & 46,62 & 56,93 & 59,36 & 57,80 & 63,03 & 59,09 & 57,78 & 5,71 & 2,38 & 28,12 & 30,39 & 4,30 \\
\hline $\mathrm{Ce}$ & 114,23 & 142,08 & 109,30 & 131,78 & 131,46 & 201,31 & 103,14 & 121,48 & 93,98 & 114,58 & 117,33 & 113,81 & 128,49 & 112,12 & 117,99 & 78,96 & 5,81 & 55,08 & 61,89 & 7,31 \\
\hline $\operatorname{Pr}$ & ,08 & 5,53 & 11,59 & 13,87 & 14,10 & 18,17 & 10,57 & 12,71 & 10,08 & 12,28 & 13,37 & 12,65 & 14,29 & 12,47 & 13,54 & 8,28 & 7,38 & & & \\
\hline $\mathrm{Nd}$ & ,22 &, 21 & 45,09 & 53,21 & 53,98 & 59,33 & 39,50 & 48,95 & 41,19 & 50,07 & 49,19 & 48,58 & 56,87 & 48,19 & 54,98 & 30,41 & 26,55 & 23,59 & 25,09 & 23,00 \\
\hline $\mathrm{Sm}$ & &, 80 & 7,75 & & 9,16 & 32 & 6,71 & 8,70 & 7,44 & 9,07 & 9,28 & 9,04 & 10,19 & 8,57 & 10,34 & 5,00 & ,34 & ,90 & 1,86 & 3,73 \\
\hline $\mathrm{Eu}$ & & 77 & 92 & & &, 81 & 78 & 90 & & 80 & &, 50 & 84 &, 55 & 3,09 & ,44 & ,24 & ,04 & 18 & 1,16 \\
\hline $\mathrm{Gd}$ & & & & & & & & & & & & & & & & 3,57 & 2,71 &, 55 & 3,57 & 2,47 \\
\hline $\mathrm{Tb}$ & & & & & & & & & & & & & & & & & & & & \\
\hline Dy & & & & & & & & & & & & & & & & & & ,39 & 2,87 & 1,42 \\
\hline Ho & & & & & & & & & & & & & & & & &, 25 & 0,26 & & 0,17 \\
\hline Er & & & & & 1,43 & & & & 1,38 & & 2,29 & 1,51 & 1,45 & 1,40 & 1,55 & 0,87 & 0,67 & 0,63 & 1,58 & 0,44 \\
\hline $\mathrm{Tm}$ & & 0,10 & 0,25 & 0,19 & 0,20 & 0,21 & 0,19 & 0,27 & 0,19 & 0,21 & 0,33 & 0,19 & 0,19 & 0,18 & 0,19 & 0,12 & 0,10 & & & \\
\hline $\mathrm{Yb}$ & & 1,00 & 1,49 & & 1,27 & 1,35 & 1,26 & 1,78 & 1,19 & 1,35 & & 1,08 & 1,12 & 1,02 & 1,07 & 0,81 & 0,65 & 0,45 & 1,42 & 0,53 \\
\hline $\mathrm{Lu}$ & & & & & & & & & & & & & 0,15 & 0,14 & 0,14 & 0,12 & 0,09 & 0,12 & 0,20 & 0,06 \\
\hline $\mathrm{Ta}$ & & & & & & & & & & & & & & & & 0,97 & & - & - & - \\
\hline Th & & 18,69 & 15,49 & 19,55 & 19,58 & 24,34 & 13,69 & 18,25 & 8,40 & 11,08 & 15,97 & 13,05 & 7,99 & 10,11 & 5,41 & 12,06 & 12,87 & - & - & - \\
\hline $\mathrm{U}$ & 5,14 & 6,23 & 5,35 & 6,19 & 5,85 & 6,88 & 5,15 & 6,10 & 3,07 & 3,00 & 6,51 & 3,81 & 2,74 & 2,82 & 2,65 & 5,25 & 5,55 & - & - & $\begin{array}{lll}- & - \\
\end{array}$ \\
\hline
\end{tabular}

rito Arroio do Jacques e Monzonitos Hipabissais aponta uma tendência de queda dos teores de $\mathrm{TiO}_{2}, \mathrm{CaO}, \mathrm{MgO}$, $\mathrm{Fe}_{2} \mathrm{O}_{3}{ }^{\mathrm{T}}, \mathrm{MnO}$ e $\mathrm{P}_{2} \mathrm{O}_{5}$ com o aumento do índice de diferen- ciação, comum em sistemas evoluídos a partir de cristalização fracionada (Fig. 5). Dispersões nos teores de $\mathrm{Al}_{2} \mathrm{O}_{3}$, $\mathrm{Na}_{2} \mathrm{O}, \mathrm{K}_{2} \mathrm{O}, \mathrm{Rb}$, Sr e Ba, observados em algumas amostras 

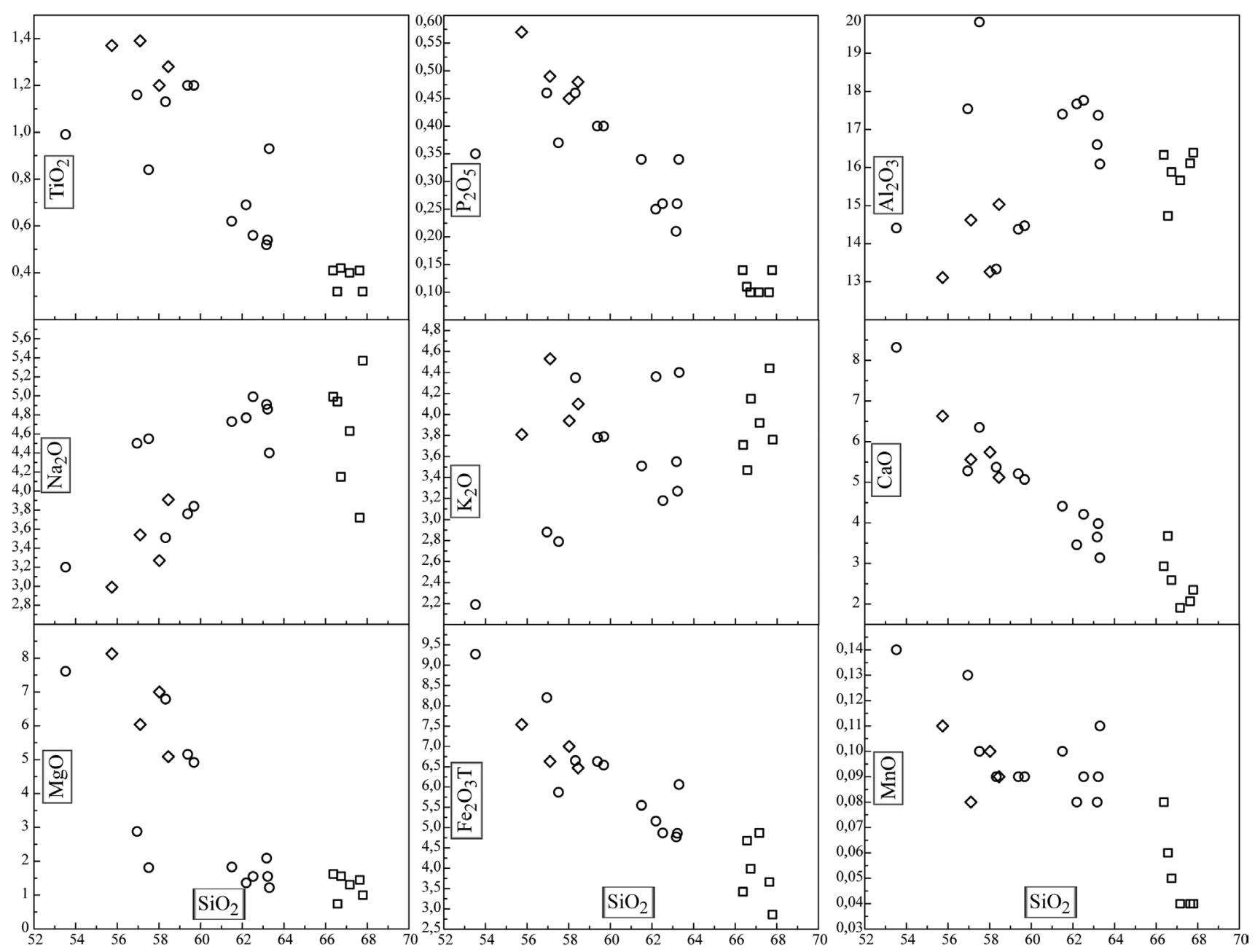

Figura 5 - Diagramas de Harker das rochas monzoniticas da ASLS. Valores em percentagem de peso.

refletem processos de acumulação de cristais (Fig. 5 e 6).

Os conteúdos de $\mathrm{Rb}, \mathrm{Ba}$ e $\mathrm{Sr}$ das rochas do Monzonito Tapera, Monzodiorito Arroio do Jacques e Monzonitos Hipabissais são relativamente elevados e típicos de rochas de afinidade shoshonítica (Lima 1995, Lima \& Nardi 1998).

O Zr varia de $114 \mathrm{ppm}$ a $290 \mathrm{ppm}$ e apresenta um padrão de distribuição com decréscimo nos conteúdos com o aumento do índice de diferenciação, sugerindo fracionamento de zircão.

Os padrões de ETR das rochas, obtidos com a normalização dos dados pelo padrão condrítico $\mathrm{C} 1 \mathrm{de}$ Sun e McDonough (1989) mostram forte enriquecimento de ETRL em relação aos ETRP (Fig. 7). As amostras do Monzonito Tapera e do Monzodiorito Arroio do Jacques mostram elevados conteúdos de ETR $\left(\mathrm{Ce}_{\mathrm{N}} \cong 200 \mathrm{e} \mathrm{Yb}_{\mathrm{N}} \cong\right.$ 8) em relação as do Monzonito Hipabissal $\left(\mathrm{Ce}_{\mathrm{N}} \cong 120 \mathrm{e}\right.$ $\mathrm{Yb}_{\mathrm{N}} \cong 3$ ), sendo observadas nos três grupos pequenas anomalias de Eu. As rochas intermediárias e ácidas de natureza shoshonítica caracterizam-se por possuírem em geral, um conteúdo global de ETR entre 124 - 387 ppm com fracas anomalias de Eu (Henderson, 1984). As rochas estudadas enquadram-se neste intervalo, constatando-se um somatório de ETR que varia de 133 a 319 ppm.
Possuem um carácter álcali-cálcico (Fig. 8) e ocupam o campo das rochas shoshoníticas no diagrama de Liégeois et al. (1998), que utiliza a média dos teores de Zr-Ce-Sm-Y-Yb versus a média de Rb-Th-U-Ta ambas normalizadas pelo NYTS (Fig. 9).

DADOS ISOTÓPICOS A derivação mantélica das rochas shoshoníticas da ASLS é sugerida por Lima \& Nardi (1998) e Nardi \& Lima (2000), com base nas razões iniciais ${ }^{87} \mathrm{Sr} /{ }^{86} \mathrm{Sr}$ de 0,704 , aliadas à presença de basaltos. Para compatibilizar assinaturas isotópicas e geoquímicas, a fonte preferida é o manto litosférico enriquecido em elementos incompatíveis - tipo EM-I, originado em eventos prévios de subducção e metassomatismo do manto.

Gastal et al. (2006) sugerem, em base a novos dados geocronológicos e reinterpretações dos dados apresentados por Remus et al. (2000), que o Complexo Intrusivo de Lavras do Sul (CILS) foi formado principalmente entre $603 \mathrm{Ma}$ e $597 \mathrm{Ma}$.

No presente trabalho datou-se pelo método U-Pb SHRIMP em zircão uma amostra representativa dos Monzonitos Hipabissais, sendo selecionados grãos de zircão prismáticos subédricos a euédricos. Nestes os conteúdos de U variam de 217 ppm a 990 ppm e de Th 


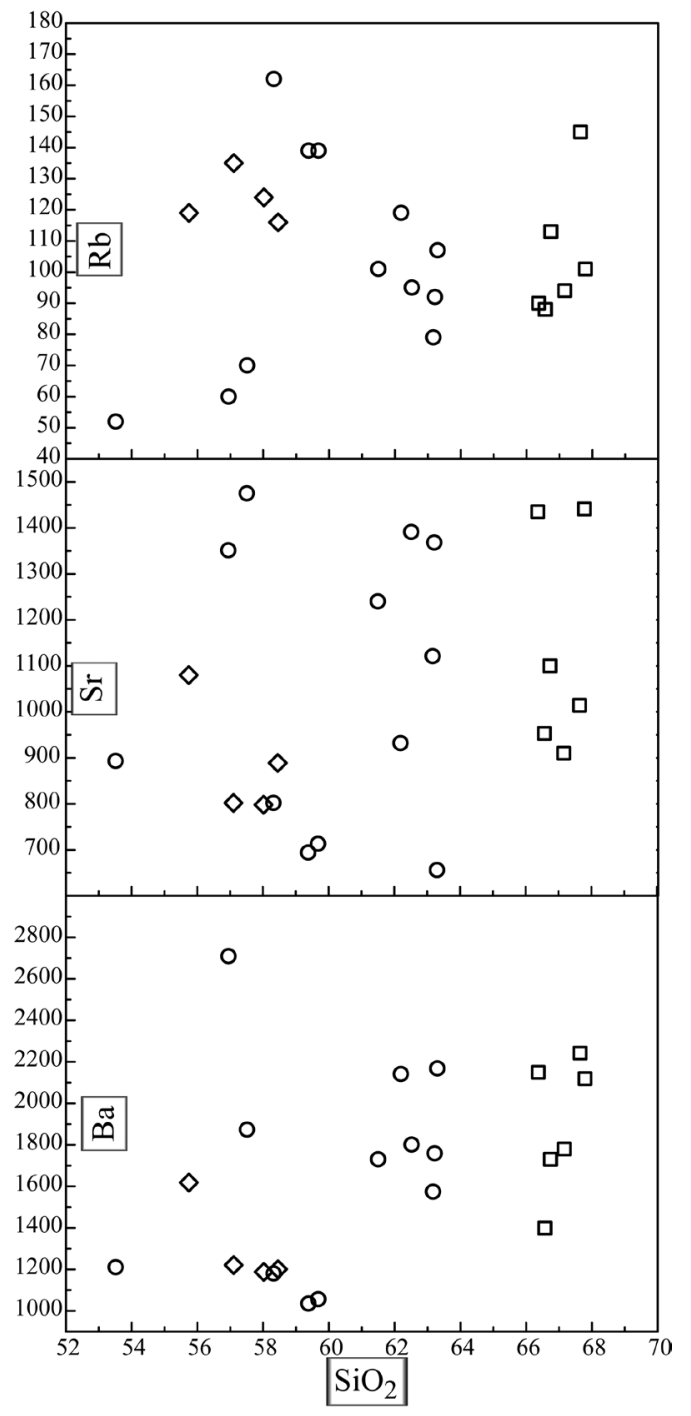

Figura 6 - Diagramas de variação de elementos-traço (ppm) versus $\mathrm{SiO}_{2}$ (percentagem de peso).

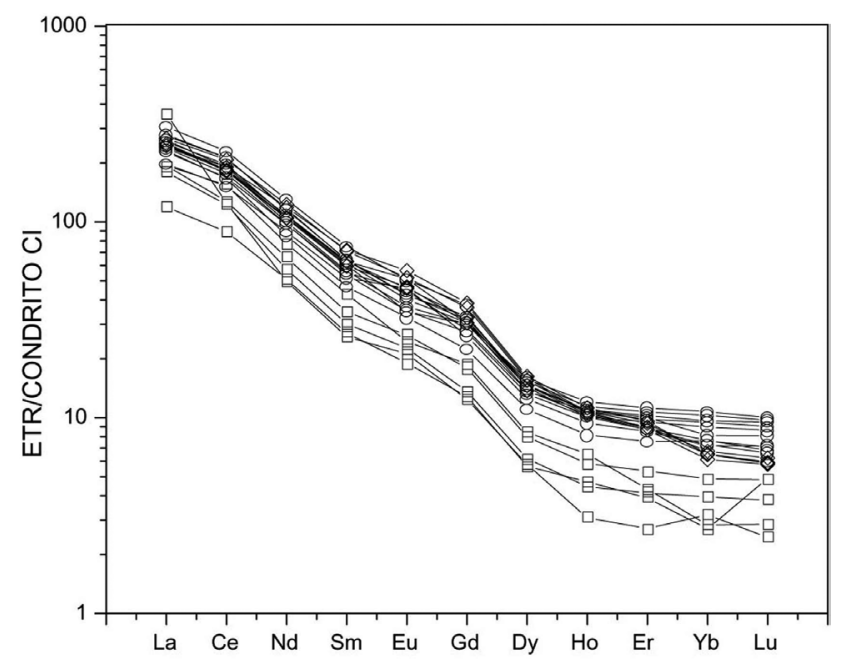

Figura 7 - Padrões de ETR das amostras do Monzonito Tapera (o), Monzodiorito Arroio do Jacques $(\diamond)$ e Monzonitos Hipabissais $(\square)$ normalizados pelo padrão condrítico $C 1$.

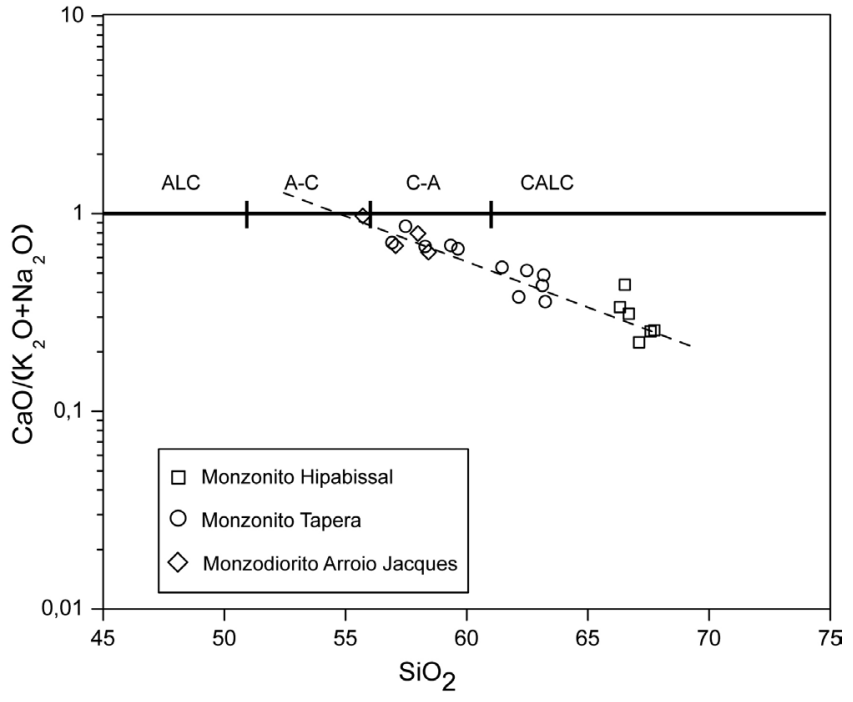

Figura 8 - Diagrama do índice de Peacock (CaO/ $\mathrm{K}_{2} \mathrm{O}+\mathrm{Na}_{2} \mathrm{O}$ vs. $\mathrm{SiO}_{2}$ ) modificado por Brown 1982. Os óxidos são expressos em percentagem de peso.

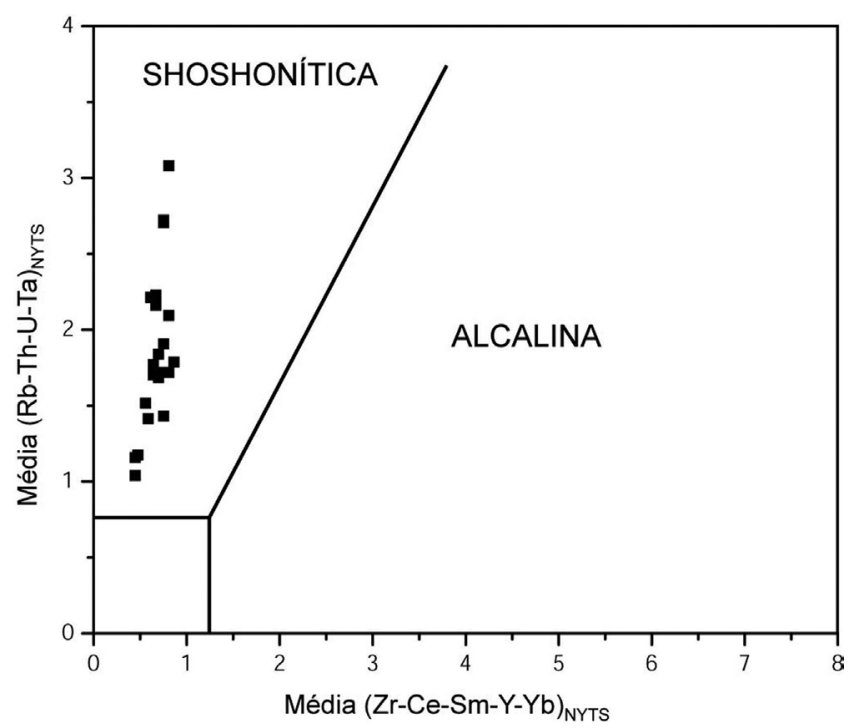

Figura 9 - Diagrama de elementos traço separando rochas de afinidade shoshonitica de rochas de afinidade alcalina (Liégeois et al.1998). Os valores dos elementos traço estão normalizados pela série de rochas Yenchichi-Telabit do Tuareg Shield - NYTS(Liégeois et al.1998).

de $81 \mathrm{ppm}$ a $340 \mathrm{ppm}$, sendo as razões de Th/U de 0,21 a 0,49 , comuns em zircões de rochas ígneas (Hinton a Upton 1991). Os dados de ${ }^{206} \mathrm{~Pb} /{ }^{238} \mathrm{U}$ definiram duas populações, uma obtida em três zircões com $606,6 \pm 6,2$ Ma $(\mathrm{MSWD}=0,1)$ e outra obtida em sete zircões com $587 \pm 4$ Ma (MSWD = 0,47) (Tab. 2). Os grãos da população mais antiga são interpretados como sendo xenocristais, herdados possivelmente das manifestações precoces da ASLS. A idade de $587 \pm 4$ Ma é atribuída à cristalização dos zircões das rochas Monzoníticas 
Tabela 2 - Sumário dos dados SHRIMP U-Pb obtidos em zircões extraídos dos Monzonitos Hipabissais.

\begin{tabular}{|c|c|c|c|c|c|c|c|c|c|c|c|c|c|c|c|c|c|c|c|c|c|}
\hline $\begin{array}{l}\text { Grain } \\
\text { Spot }\end{array}$ & $\begin{array}{c}\mathrm{U} \\
(\mathrm{ppm})\end{array}$ & \begin{tabular}{|c|} 
Th \\
$(\mathrm{ppm})$
\end{tabular} & $\begin{array}{l}{ }^{232} \mathrm{Th} \\
{ }^{238} \mathrm{U}\end{array}$ & \begin{tabular}{|l}
${ }^{206} \mathrm{~Pb}$ \\
${ }^{238} \mathrm{U}$
\end{tabular} & \pm & $\begin{array}{l}{ }^{206} \mathrm{~Pb} \\
{ }^{238} \mathrm{U}\end{array}$ & \pm & $\begin{array}{l}{ }^{207} \mathrm{~Pb} \\
{ }^{206} \mathrm{~Pb}\end{array}$ & \pm & $\begin{array}{c}\% \\
\text { Dis- } \\
\text { cor- } \\
\text { dant }\end{array}$ & $\begin{array}{l}\text { Total } \\
{ }^{238} \mathrm{U} \\
{ }^{2006} \mathrm{~Pb}\end{array}$ & \pm & $\begin{array}{l}\text { Total } \\
{ }^{207} \mathrm{~Pb} \\
{ }^{2066} \mathrm{~Pb}\end{array}$ & \pm & $\begin{array}{l}{ }^{207} \mathrm{~Pb}^{*} \\
206 \mathrm{~Pb}^{*}\end{array}$ & \pm & $\begin{array}{c}{ }^{207} \mathrm{~Pb}^{*} \\
{ }^{235} \mathrm{U}\end{array}$ & \pm & $\begin{array}{l}{ }^{206} \mathrm{~Pb}^{*} \\
{ }^{238} \mathrm{U}\end{array}$ & \pm & $\begin{array}{l}\text { err } \\
\text { corr }\end{array}$ \\
\hline 1,1 & 602 & 123 & 0,21 & 590,0 & 6,7 & 585,5 & 8,1 & 811 & 260 & 37 & 9,81 & 1,1 & 0,1158 & 2,3 & 0,0661 & 12 & 0,87 & 13 & 0,0958 & 1,2 & 0,095 \\
\hline 2,2 & 318 & 121 & 0,39 & 592,3 & 7,5 & 591,2 & 7,7 & 646 & 48 & 9 & 10,41 & 1,3 & 0,05967 & 1,3 & 0,0612 & 2,2 & 0,812 & 2,6 & 0,0962 & 1,3 & 0,511 \\
\hline 3,1 & 854 & 301 & 0,36 & 589,8 & 4,6 & 589,5 & 4,7 & 603 & 19 & 2 & 10,426 & 0,81 & 0,06089 & 0,76 & 0,05999 & 0,88 & 0,7925 & 1,2 & 0,09581 & 0,81 & 0,676 \\
\hline 9,1 & 990 & 340 & 0,35 & 582,1 & 4,2 & 581,8 & 4,3 & 595 & 61 & 2 & 10,470 & 0,73 & 0,06842 & 1,1 & 0,0598 & 2,8 & 0,779 & 2,9 & 0,09450 & 0,75 & 0,256 \\
\hline 10,1 & 723 & 282 & 0,40 & 590,5 & 4,5 & 590,9 & 4,6 & 567 & 18 & -4 & 10,426 & 0,80 & 0,05893 & 0,83 & 0,05900 & 0,83 & 0,7803 & 1,2 & 0,09592 & 0,80 & 0,696 \\
\hline 11,1 & 621 & 297 & 0,49 & 587,7 & 8,3 & 587,8 & 7,7 & 580 & 440 & -1 & 10,033 & 0,96 & 0,0940 & 6,5 & 0,059 & 20 & 0,78 & 20 & 0,0954 & 1,5 & 0,073 \\
\hline 12,1 & 581 & 229 & 0,41 & 586,5 & 4,8 & 586,5 & 4,9 & 587 & 21 & 0 & 10,492 & 0,85 & 0,06003 & 0,9 & 0,05955 & 0,95 & 0,7821 & 1,3 & 0,09526 & 0,85 & 0,665 \\
\hline 1,2 & 600 & 142 & 0,24 & 605 & 4,6 & 606,7 & 4,7 & 520 & 26 & -14 & 10,15 & 0,8 & 0,0591 & 0,9 & 0,0577 & 1,2 & 0,78 & 1,4 & 0,0984 & 0,8 & 0,555 \\
\hline 6,1 & 712 & 244 & 0,35 & 604,8 & 4,7 & 605,5 & 4,8 & 569 & 92 & -6 & 9,99 & 0,8 & 0,0728 & 0,8 & 0,0591 & 4,2 & 0,80 & 4,3 & 0,0984 & 0,8 & 0,190 \\
\hline 7,1 & 217 & 81 & 0,38 & 609,9 & 8,8 & 610,1 & 9 & 602 & 32 & -1 & 10,08 & 1,5 & 0,0596 & 1,5 & 0,0600 & 1,5 & 0,82 & 2,1 & 0,0992 & 1,5 & 0,714 \\
\hline
\end{tabular}

Hipabissais. Este dado é coerente com as relações de campo, constatando-se que os Monzonitos Hipabissais são intrusivos no Monzonito Tapera, no Monzodiorito Arroio do Jacques e na borda do granodiorito do CILS. A idade obtida nos Monzonitos Hipabissais assemelhase aos resultados de Ar-Ar obtidos em plagioclásio de traquiandesitos shoshoníticos da região de Lavras do Sul (Janikian 2004), conforme tabela 3. Esta idade dos Monzonitos Hipabissais expande o intervalo de geração do magmatismo shoshonítico para $16 \mathrm{Ma}$.

DISCUSSÃO DOS RESULTADOS As rochas monzoníticas da Associação Shoshonítica de Lavras do Sul ocorrem como rochas plutônicas (Monzonito Tapera e Monzodiorito Arroio do Jacques) e hipabissais (Monzonitos Hipabissais). Estes últimos constituem intrusões ressurgentes rasas, vinculadas a uma estruturação de colapso de caldeira. Os dados de campo apoiados em resultados geocronológicos permitiram organizar estratigraficamente estes litotipos.

O Monzonito Tapera é representado por rochas dioríticas a monzoníticas, com cumulados leucodioriticos subordinados. O Monzodiorito Arroio do Jacques possui os termos menos diferenciados das rochas intrusivas, com ortopiroxênio dioritos que evoluem até monzonitos.

Os Monzonitos Hipabissais são constituídos por feldspato alcalino e o plagioclásio, cuja composição varia de andesina a oligoclásio, acompanhados de uma associação mineral metaluminosa, constituída por magnésio hornblenda + augita-diopsídio \pm biotita, sendo a titanita, o zircão e a apatita os minerais acessórios. Este litotipo é sucedido por diques classificados como latíticos, rocha composta e dique autoclástico, que podem representar condutos alimentadores das últimas manifestações vulcânicas na região.

Dados de litoquímica obtidos no Monzonito Tapera, no Monzodiorito Arroio do Jacques e nos Monzonitos Hipabissais mostram conteúdos elevados de LILE ( $\mathrm{Ba}, \mathrm{Sr}, \mathrm{Rb}$ ) e moderados de HFSE ( $\mathrm{Zr}, \mathrm{Nb}, \mathrm{Y})$. Os padrões de ETR das rochas, quando normalizados pelo condrito C1 de Sun \& McDonough (1989), possuem enriquecimento em ETRL em relação aos ETRP, e não apresentam anomalias significativas de Eu. Este conjunto de características é típico de rochas da ASLS e da série shoshonítica em geral (Lima e Nardi 1998).

Os diagramas de correlação da $\mathrm{SiO}_{2}$ com ele-

Tabela 3 - Idades geocronológicas das rochas da ASLS.

\begin{tabular}{|c|c|c|c|}
\hline LITOTIPO & IDADE & MÉTODO & AUTOR \\
\hline Monzonito Tapera & $601 \pm 5 \mathrm{Ma}$ & $\mathrm{Pb}-\mathrm{Pb}$ por evaporação & Gastal e Lafon (2001) \\
\hline Monzodiorito Arroio do Jacques & $599 \pm 7 \mathrm{Ma}$ & $\mathrm{Pb}-\mathrm{Pb}$ por evaporação & Gastal e Lafon (2001) \\
\hline Núcleo do CGLS & $594 \pm 4 \mathrm{Ma}$ & U-Pb SHIRIMP & Remus et al. (2000) \\
\hline Andesitos & $\begin{array}{l}586 \pm 8 \mathrm{Ma} \mathrm{e} \\
588 \pm 7 \mathrm{Ma}\end{array}$ & Ar/Ar (plagioclásio) & Janikian (2004) \\
\hline Monzonito Hipabissal & $587 \pm 4 \mathrm{Ma}$ & U-Pb SHIRIMP & Liz et al. neste artigo \\
\hline
\end{tabular}


mentos maiores e traços indicam que os trends magmáticos foram gerados por processos de cristalização fracionada a partir de magmas shoshoníticos menos diferenciados.

Os valores mais baixos de ETR são encontrados nos Monzonitos Hipabissais, que são os litotipos mais evoluídos. Este decréscimo nos conteúdos de ETR durante a diferenciação magmática pode ser explicado pelo fracionamento de fases enriquecidas nestes elementos tais como hornblenda, apatita, zircão e alanita. Os padrões de ETR são típicos de magmas shoshoníticos e, portanto, reforçam a natureza não cumulática das rochas monzoníticas da Associação Shoshonítica de Lavras do Sul. Pequenas anomalias de Eu são atribuídas a segregações localizadas de feldspatos.

Neste contexto, os Monzonitos Hipabissais aflorantes na porção nordeste da área são interpretados como unidades intrusivas ressurgentes, portanto tardias na história evolutiva da área. Estes corpos ressurgentes podem ter sido temporalmente acompanhados por efusivas intermediárias de mesma afinidade geoquímica e pelo magmatismo alcalino sódico representado pelo pertita granito, conforme sugere os dados geocronológicos de Jenikian (2004) e as re-interpretações de Gastal et al. (2006). Estas manifestações finais marcadas pelo magmatismo concomitante shoshonítico e alcalino sódico devem ter causado um importante incremento no gradiente geotermal da área. Este deve ter contribuído na remobilização de metais básicos por ação do hidrotermalismo e na geração das mineralizações de Au$\mathrm{Cu}$ tipo pórfiro encontradas na região de Lavras do Sul conforme discutido por Liz et al. (2004). Esta hipótese é coerente com os dados geocronológicos apresentados por Bongiolo et al. (2003) para os granitos hidrotermalizados de Lavras do Sul, o que abre a possibilidade de ocorrerem mineralizações de $\mathrm{Au}-\mathrm{Cu}$ na porção nordeste da área, vinculadas ao hidrotermalismo nas rochas vulcânicas.

CONCLUSÕES As rochas monzoníticas da ASLS ocorrem como rochas plutônicas (Monzonito Tapera e Monzodiorito Arroio do Jacques) e hipabissais (Monzonitos Hipabissais). Estes últimos constituem intrusões ressurgentes rasas, vinculadas a uma estruturação de colapso de caldeira. Os dados de campo, petrográficos e geoquímicos indicam que estes litotipos representam a cristalização de magmas de afinidade shoshonítica, com feições cumuláticas localizadas.

A interpretação dos dados geoquímicos permite explicar a origem das rochas monzoníticas pela cristalização fracionada de magmas menos diferenciados de mesma afinidade, concluindo-se pelo caráter cogenético das mesmas e de sua vinculação com ASLS.

A idade obtida de $587 \pm 4$ Ma obtida nos Monzonitos Hipabissais permite sugerir que estes litotipos representam manifestações shoshoníticas tardias da área e definem, considerando a idade de 603 Ma para as primeiras manifestações do CILS (Gastal et al. 2006), um intervalo de formação da ASLS de pelo menos 16 Ma.

Agradecimentos Os autores expressam seus agradecimentos ao Programa de Pós-Graduação em Geociências do IG-UFRGS pela infra-estrutura disponibilizada, ao $\mathrm{CNPa}$ pela bolsa de doutorado e de produtividade científica e aos revisores da Revista Brasileira de Geociências.

\section{Referências}

Bongiolo E.M., Mexias A.S., Santos J.O.S., Hartmann L.A., Conceição R.V., Gomes M.E.B., Formoso M.L.L. 2003. Geocronologia do hidrotermalismo versus magmatismo do Distrito Aurífero de Lavras do Sul. In: SBG, Encontro de Estratigrafia do Rio Grande do Sul: Escudo e Bacias, 1, Anais, p. 83-88.

Brögger W.C. 1895. Eruptivgesteine des Kristianiagebietes. In: Johannsen A. 1937. A descriptive Petrography of the Igneous Rocks vol. III, The intermediate Rocks. Chigaco, The University of Chicago Press, p. 95.

Brown G.C. 1982. Calc-alkaline intrusive rocks: their diversity, evolution, and relation to volcanic arcs. In: Thorpe R.S. (ed.) Andesites: Orogenic Andesites and related rocks. London, John Wiley, p. 437-460.

Compston W., Willians I.S., Meyer C. 1984. Geochronology of zircons from the lunar breccia 73217 using a sensitive high mass resolution ion microprobe. Journ. of Geoph. Res., 89 (Supp. B):525-534.

Gastal M.C.P., Ferreira F.J.F., Lafon J.M., Hartmann L.A. 2004. Monzodiorito Arroio do Jacques: Importância na evolução petrológica do Complexo Intrusivo Lavras do Sul, RS. In: SBGq, Congr. Bras. de Geol., 42, Anais, nº 23. p.1239, CD-ROOM.
Gastal M.C.P. \& Lafon J.M. 2001. Novas Idades 207Pb/206Pb e Geoquímica Isotópica Nd-Sr para Granitóides Shoshoníticos e Alcalinos das Regiões de Lavras do Sul e Taquerembó, RS. In: SBGq, Congr. Bras. de Geoqu., 1 e Simp. de Geoqu. dos Países do Mercosul, 8, Anais, RS 094, p.7, CD-ROOM.

Gastal M.C.P. \& Lafon J.M. 2006.. Reinterpretação do Complexo Intrusivo Lavras do Sul, RS, de acordo com os sistemas vulcano-plutônicos de subsidência. Parte 2: química mineral, geoquímica e isótopos $\mathrm{Pb}-\mathrm{Sr}-\mathrm{Nd}$. Rev. Bras. de Geoc., 36(1):125-146.

Gastal M.C.P., Lafon J.M., Ferreira J.F.F., Magro J.F.U., Remus M.V.D., Sommer C.A. 2006. Reinterpretação do Complexo Intrusivo Lavras do Sul, RS, de acordo com os sistemas vulcano-plutônicos de subsidência. Parte 1: geologia, geofísica e geocronologia $(207 \mathrm{~Pb} / 206 \mathrm{~Pb}$ e $206 \mathrm{~Pb} / 238 \mathrm{U})$. Rev. Bras. de Geoc., 36(1):109-124.

Henderson P. 1984. Rare earth elements geochemistry. Amsterdam, Elsevier, 510p.

Hinton R.W. \& Upton B.G.J. 1991. The chemistry of zircon: variations within and between large crystals from syenite and alkali

basalt xenoliths. Geochimica et Cosmochimica Acta, 
$\mathbf{5 5}(11): 3287-3302$.

Janikian L. 2004. Seqüências deposicionais e evolução paleoambiental do Grupo Bom jardim e da Formação Acampamento Velho, Supergrupo Camaquã, Rio Grande do Sul. Tese de Doutoramento, Instituto de Geociências, USP, $189 \mathrm{p}$.

Lapparent A.A.A. de. 1864. Mémoire sur la constitution géologique du Tyrol, méridional. Annales des Mines ou Recueil de Mémoires sur l'Exploration des Mines, et sur les Sciences qui s'y rapportent: rediges par le Conseil General dês Mines, Paris, 6:245-314.

Le Maitre R. W. 2002. A classification of igneous rock and glossary of terms: recomendations of the Internation Union of Geologycal Sciencies Subcommission of the Systematics of Igneous Rocks. $2^{\text {nd }}$ edition, Oxford, Blackwell Scientific Publications, 236p.

Liégeois J.P., Navez J., Hertogen J., Black R. 1998. Contrasting origin of post-collisional high-K calc-alkaline and shoshonitic versus alkaline and peralkaline granitoids. The use of sliding normalizantion. Lithos, 45:1-28.

Lima E.F. 1995. Petrologia das Rochas Vulcânicas e Hipabissais da Associação Shoshonítica de Lavras do Sul $A S L S, R S$. Tese de Doutoramento, Instituto de Geociências, Universidade Federal do Rio Grande do Sul, 338p.

Lima E.F. \& Nardi L.V.S. 1998. The Lavras do Sul Shoshonitic Association: Implications for Origin and Evolution of Neoproterozoic Shoshonitic Magmatism in Southermost Brazil. Journal South American Earth Sciences, 11:67-77.

Liz J.D., Lima E.F., Nardi L.V.S., Hartmann L.A., Sommer C.A., Gonçalves C.R.H. 2004. Aspectos petrográficos, composicionais e potencialidade para mineralizações de ouro e sulfetos do sistema multi-intrusivo da Associação Shoshonítica de Lavras do Sul (RS). Rev. Bras. Geoc., 34(4):539-552.

Nachit H., Razafimahefa N, Stussi J.M., Carron J.P. 1985. Composition chimique des biotites et typologie magmatique des granitoides. C.R. Acad. Sci. Paris, Sér.II, 301(11):813-818.
Nardi L.V.S. 1984. Geochemistry and Petrology of the Lavras Granite Complex, RS, Brasil. Tese de Doutoramento, Universidade de Londres, 268p.

Nardi L.V.S. \& Lima E.F. 1985. A Associação Shoshonítica de Lavras do Sul, RS. Rev. Bras. Geol., 15(2):139-146.

Nardi L.V.S. \& Lima E.F. 2000. O Magmatismo Shoshonítico e Alcalino da Bacia do Camaquã - RS. In: Holz M. \& De Ros L.F. (eds.) Geologia do Rio Grande do Sul. Porto Alegre, RS, p. 119-131.

Nekvasil H. 1992. Ternary feldspar crystallization in hightemperature felsic magmas. Am. Miner., 77:592-604.

Remus M.V.D., Hartmann L.A., Mcnaughton N.J., Groves D.I., Reischl J.L. 2000. Distal magmatic-hydrothermal origin for the Camaquã $\mathrm{Cu}(\mathrm{Au}-\mathrm{Ag})$ and Santa Maria $\mathrm{Pb}, \mathrm{Zn}$ (Cu-Ag) deposits, southern Brazil. Gondw. Res., 3(2):155174.

Smith J.B., Barley M.E., Groves D.I., Krapez B., Mcnaughton N.J., Bichle J., Chapman H.J. 1998. The Scholl Shear Zone, West Pilbara: evidence for a domain boundary structure from integrated tectonostratigraphic analyses, SHRIMP U/ $\mathrm{Pb}$ dating and isotopic and geochemical data of granitoids. Prec. Res., 88:143-171.

Stabel L.Z., Nardi L.V.S., Pla Cid J. 2001. Química mineral e evolução petrologica do Sienito Piquiri: magmatismo shoshonítico, neoproterozóico, pós-colisional no sul do Brasil. Rev. Bras. Geoc., 31:211-222.

Sun S.S. \& Mcdonough W.F. 1989. Chemical and Isotopic Systematics of oceanic basalts: Implications for Mantle Composition and processes. In: Saunders A.D. \& Norry M.J. (eds.) Magmatism in Ocean Basins. London, Geol. Soc. London Spec. Pub., 42:313-345.

Von Buch L. 1824. Über geognostische Erscheinungen im Fassathale. Leonhard's Taschenbuch, 1:345-347.

Wager L.R. \& Vincent E.A. 1962. Ferrodiorite from the Isle of Skye. Mineralog. Mag. and J. Mineralog. Soc., 33:26-36.

Manuscrito ID 8332

Submetido em 20 de julho de2007 Aceito em 18 de junho de 2009 